\title{
High rates of bacterial vaginosis and Chlamydia in a low-income, high-population-density community in Cape Town
}

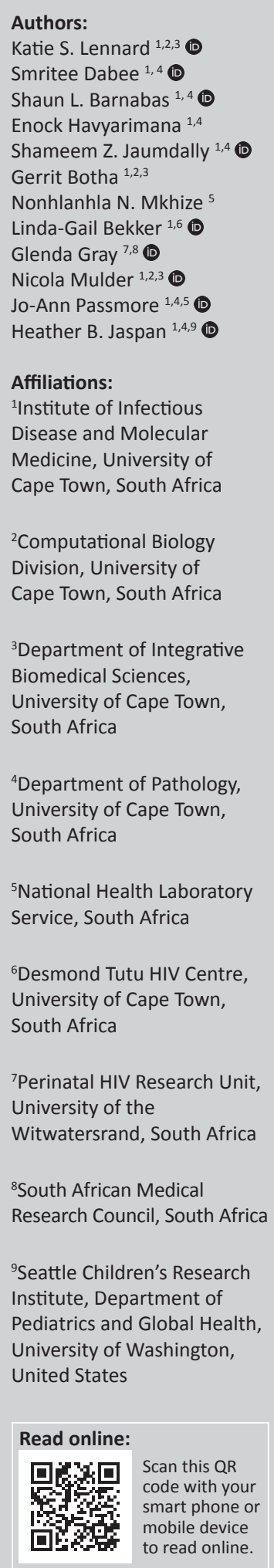

Young South African women, from resource-poor communities, face several sexual and reproductive health challenges. Here we describe the vaginal microbiota and sexually transmitted infection (STI) prevalence of 102; 16-22-year-old, HIV-negative South African women from a low-income, highpopulation-density community in Cape Town (CPT). Vaginal microbiota were profiled using $16 \mathrm{~S}$ rRNA amplicon sequencing; bacterial vaginosis (BV) status was established using Nugent scoring and STIs were determined by multiplex polymerase chain reaction. STIs were common, with $55 \%$ of women having at least one STI; $41 \%$ were infected with high-risk human papilloma virus (HPV) and a further $28 \%$ with low-risk HPV; $44 \%$ were infected with Chlamydia, $16 \%$ of whom had at least one additional STI. Similarly, BV rates were very high, with $55 \%$ of women classified as BV-positive (Nugent score $\geq 7$ ), 7\% as BV-intermediate (Nugent score 3-6) and 38\% as BV-negative (Nugent 0-2). Group B Streptococcus (Streptococcus agalactiae), the leading cause of neonatal sepsis, was present in $25 \%$ of BV-positive women and $28 \%$ of BV-negative women, and was significantly more abundant among BV-negative women. Both Chlamydia infection and BV may adversely affect reproductive health and place these women at additional risk for HIV acquisition. The high abundance of Prevotella amnii, in particular, may increase HIV risk, given its inflammatory capacity. Laboratorybased testing for STIs (Chlamydia and Gonorrhoeae in particular) appear to be warranted in this community, together with further monitoring or treatment of BV.

Research correlation: This article is the original version, of which an Afrikaans translation was made available to provide access to a larger readership, available here: https://doi.org/10.4102/ satnt.v36i1.1495

Hoë voorkomskoers van bakteriële vaginose en Chlamydia in 'n lae-inkomste, hoëbevolkingsdigtheid gemeenskap in Kaapstad. Jong Suid-Afrikaanse vroue uit hulpbron-arm gemeenskappe staar verskeie uitdagings in die gesig in terme van hul seksuele en reproduktiewe gesondheid. Hier beskryf ons die voorkoms van vaginale mikrobiota en seksueel oordraagbare infeksies (SOI's) onder 102; 16-22-jarige MIV-negatiewe Suid-Afrikaanse vroue uit 'n lae-inkomste, hoë-bevolkingsdigtheid gemeenskap in Kaapstad. Vaginale mikrobiota is met behulp van 16S rRNA amplikon volgorde-bepaling geprofileer; bakteriese vaginose (BV) status is met behulp van 'n Nugent-telling vasgestel; en SOI's is deur middel van 'n multipleks polimerase kettingreaksie bepaal. SOI's was algemeen, met $55 \%$ van die vroue wat ten minste een SOI gehad het; $41 \%$ wat met hoë-risiko menslike papillomavirus (MPV) besmet was, en 'n verdere $28 \%$ wat met laerisiko-MPV besmet was; $44 \%$ van die vroue was met Chlamydia besmet, waarvan $16 \%$ een of meer addisionele SOI gehad het. BV persentasies was ook baie hoog, met $55 \%$ van die vroue wat as BV-positief (Nugent-telling $\geq 7$ ) geklassifiseer is, $7 \%$ as BV-intermediêr (Nugent-telling 3-6), en 38\% as BVnegatief (Nugent-telling 0-2). Streptococcus (Streptococcus agalactiae), die grootste oorsaak van neonatale sepsis, was teenwoordig in $25 \%$ van die $B V$-positiewe vroue en $28 \%$ van die BV-negatiewe vroue, en was dus meer onder BV-negatiewe vroue. Beide Chlamydia-infeksie en BV kan reproduktiewe gesondheid nadelig beïnvloed en verhoog hierdie vroue se risiko vir die verkryging van MIV. Die voorkoms van veral Prevotella amnii kan die MIV-risiko verhoog as gevolg van sy inflammatoriese kapasiteit. Laboratorium-gebaseerde toetsing vir SOI's (veral Chlamydia en Gonorrhoeae) blyk in hierdie gemeenskap geregverdig te wees, tesame met verdere monitering en/ of behandeling van BV.

Navorsing korrelasie: Hierdie artikel is die oorspronklike weergawe, waarvan ' $\mathrm{n}$ Afrikaanse vertaling beskikbaar gestel is met die doel tot ' $n$ breër lesersgroep, beskikbaar hier: https://doi. org/10.4102/satnt.v36i1.1495

Corresponding author: Katie Lennard, katieviljoen@gmail.com

Dates: Received: 09 Oct. 2017 | Accepted: 01 Nov. 2017 | Published: 12 Dec. 2017

How to cite this article: Lennard, K.S., Dabee, S., Barnabas, S.L., Havyarimana, E., Jaumdally, S.Z. \& Botha, G. et al., 2017, 'High rates of bacterial vaginosis and Chlamydia in a low-income, high-population-density community in Cape Town', Suid- Afrikaanse Tydskrif vir Natuurwetenskap en Tegnologie 36(1), a1484. https://doi.org/10.4102/satnt.v36i1.1484 


\section{Introduction}

Young South African women from resource-poor communities face several sexual and reproductive health challenges. The incidence of HIV is disproportionately high in adolescent and young women in sub-Saharan Africa, relative to their male counterparts. Several factors may contribute, including lack of sexual and reproductive health education and inadequate public health services. One important additional HIV risk factor that appears to be unrelated to behaviour is genital inflammation (Masson et al. 2015). Several factors have been proposed to cause genital inflammation, including bacterial vaginosis (BV) (characterised by increased vaginal microbial diversity and a decrease in the proportion of Lactobacilli) and sexually transmitted infections (STIs). These factors appear to be interdependent, as BV is associated with increased risk of STIs (Balkus et al. 2014; Gallo et al. 2012; Wiesenfeld et al. 2003), including HIV (Atashili et al. 2008; Myer et al. 2005; Taha et al. 1998), and vice versa (Gallo et al. 2012). BV is more prevalent in women of African descent, compared to European women (Buvé et al. 2014; Ravel et al. 2010; Srinivasan et al. 2012), with extremely high rates in South Africa $(34 \%-58 \%)$, relative to other countries (Kenyon, Colebunders \& Crucitti 2013).

Human papilloma virus (HPV) infections pose additional health concerns as high-risk HPV types are causally implicated in virtually all cases of cervical cancer. Cervical cancer has an incidence of about 30/100 000 in sub-Saharan Africa - fivefold higher than in developed countries such as Australia, where HPV vaccination has been available since 2007 (Ferlay et al. 2015). In 2000 the South African National Department of Health introduced a national cervical cancer screening policy, allowing women over the age of 30 access to three free Papanicolaou (Pap) smears, one every 10 years (Harries et al. 2009). In 2014 HPV prophylactic vaccination was implemented in South African schools by the South African National Department of Health for all girls 9 years and older in Grade 4 in public schools, targeting almost half a million girls.

Reproductive and neonatal health represents another major concern among these young women, with $19 \%$ of SA women having had an adolescent pregnancy (10-19 years of age), $16 \%$ of which were unwanted (Mchunu et al. 2012). STIs such as Chlamydia may lead to pelvic inflammatory disease (PID), infertility, increased risk of ectopic pregnancy, or miscarriage (Anschuetz et al. 2012; Baud et al. 2011; Gottlieb, Xu \& Brunham 2013; Haggerty et al. 2010), especially if left untreated. Further, S. agalactiae (also known as group B Streptococcus or GBS) is the leading cause of neonatal sepsis, and invasive $S$. agalactiae disease is common among SA infants (Madhi et al. 2003), with transmission from the mother's genital tract, representing a major risk factor for early disease (in the first six days of life) (Edmond et al. 2012).

Here, we describe the vaginal microbiota and prevalence of STIs in 16-22-year-old, HIV-negative South African women from a low-income, high-population-density community in Cape Town (CPT), and highlight the sexual and reproductive health challenges faced by these women.

\section{Materials and methods Participant selection and sample collection}

HIV-negative South African women, aged 16-22 years, were recruited as part of the Women's Initiative in Sexual Health Study (WISH), from a low-income, high-population-density community in CPT. All participants $\geq 18$ years provided informed consent, while assent and parental consent were obtained for participants $\leq 18$ years. Young women were enrolled if they were HIV-negative, in general good health, not pregnant or menstruating at the time of sampling, and who reported no unprotected sex or douching in the previous $48 \mathrm{~h}$. Additional exclusion criteria were use of antibiotics in the prior two weeks. Study visits were scheduled two weeks after injection for participants on injectable progestin contraceptives, or otherwise during the luteal phase of their menstrual cycles (between day 14 and 28), if they were not using any hormonal contraceptives (HCs), or if they were using oral HCs. Before specimen collection, the following were performed: HIV pre-test and risk-reduction counselling, an $\mathrm{HIV}$ rapid test (Alere Determine ${ }^{\mathrm{TM}} \mathrm{HIV}-1 / 2 \mathrm{Ag} / \mathrm{Ab}$ Combo, Alere, Waltham, MA), a pregnancy test (U-test Pregnancy strip, Humor Diagnostica, Pretoria, South Africa) and a general physical examination. Genital samples were collected, using a disposable menstrual cup (Softcup ${ }^{\circledR}$ ) placed over the cervix for an hour and vaginal swabs (after cup removal) for STI testing, Nugent scoring and microbiome analysis. Women were followed longitudinally for a total of three visits; every two months if they were using Norethisterone enanthate (Net-EN), combined oral contraceptives or barrier contraception only, or every three months if they were using depot medroxyprogesterone acetate (DMPA).

\section{Sexually transmitted infection and bacterial vaginosis testing}

Vulvo-vaginal swabs were collected for STI testing by multiplex polymerase chain reaction (PCR) (Chlamydia trachomatis, Neisseria gonorrhoeae, Trichomonas vaginalis, Mycoplasma genitalium, HSV-1 and -2, Haemophilus ducreyi, Treponema pallidum and Lymphogranuloma venereum) as previously described (Lewis et al. 2012). Blood was obtained for the HIV rapid and HSV-2 serological testing. Endo-cervical swabs were collected for HPV detection and genotyping by Roche Linear Array (Mbulawa et al., submitted). The following HPV types were considered high-risk HPV: 16, 18, $31,33,35,39,45,51,52,56,58,59,66,68$ (Jacobs et al. 1997). For analyses referring to STI (any), women considered positive had to have at least one of the STIs tested for in this study (excluding HPV). Lateral wall/posterior fornix swabs were collected for Nugent scoring to classify samples as BVnegative (Nugent 0-3), intermediate (Nugent 4-6) or positive (Nugent 7-10), and vaginal $\mathrm{pH}$ was measured using colourfixed indicator strips (Macherey-Nagel, Düren, Germany).

\section{Bacterial 16S rRNA gene polymerase chain reaction amplification and sequencing}

All visit-one samples were selected for $16 \mathrm{~S}$ rRNA gene amplification by PCR with subsequent amplicon sequencing. 
Swabs were thawed, treated with a cocktail of mutanolysin (25kU/ml, Sigma Aldrich), lysozyme $(450 \mathrm{kU} / \mathrm{ml}$, Sigma Aldrich), and lysostaphin (4kU, Sigma Aldrich), then mechanically disrupted with a BeadBeater. DNA was extracted, using the MoBio PowerSoil DNA extraction kit (MoBio, Carlsbad, CA). The V4 region of the 16S rRNA gene was amplified, using modified universal primers (Pearce, Hilt \& Rosenfeld 2014): 515F (TCG TCG GCA GCG TCA GAT GTG TAT AAG AGA CAG NNN NNG TGC CAG CMG CCG CGG TAA) and 806R (GTC TCG TGG GCT CGG AGA TGT GTA TAA GAG ACA GNN NNN GGA CTA CHV GGG TWT CTA AT), and quality checked with Bioanalyzer (Agilent, Santa Clara, CA, United States). Pooled duplicate samples were purified with AMPure XP beads (Beckman Coulter, Brea, CA, United States), and quantified, using the Picogreen dsDNA assay (Invitrogen, Carlsbad, CA, United States). Amplicons were pooled in equimolar amounts and purified libraries consisting of $\sim 100$ pooled samples were paired-end sequenced on an Illumina MiSeq platform (300 bp pairedend with V3 chemistry).

Following demultiplexing, raw reads were preprocessed as follows: forward and reverse reads were merged, using usearch7 (Edgar 2010), allowing a maximum of three mismatches; merged reads were quality filtered, using usearch7 (reads with E scores larger than 0.1 were discarded); primer sequences were removed, using a custom Python script; merged, filtered reads were truncated at $250 \mathrm{bp}$. Next, sequences were de-replicated while recording the level of replication for each sequence using usearch7. De-replicated sequences were sorted by abundance (highest to lowest) and clustered de novo into operational taxonomic units (OTUs) at 97\% similarity, using usearch7. Chimeric sequences were detected (against the Gold database), using UCHIME (Edgar et al. 2011) and removed. Individual sequences were assigned to the specific identifiers, using a $97 \%$ similarity threshold. Taxonomic assignment was performed in QIIME 1.8.0 (Caporaso et al. 2010), using the RDP classifier (at the default confidence level of 0.5 ) against the Greengenes 13.8 reference taxonomy for $97 \%$ identity. To increase species level resolution, we next searched our representative de novo OTU sequences against the custom taxonomic database of Fettweis et al. (2012) and performed BLAST searches against the NCBI nucleotide database, as previously described (Lennard et al. 2017).

Samples with $\geq 5000$ reads were selected for downstream analyses. The OTU table was standardised (i.e. transformed to relative abundance * median sample read depth), and filtered so that each OTU had to have at least 10 counts in at least $2 \%$ of samples or have a relative abundance of at least $0.001 \%$.

\section{Statistical analyses}

All downstream statistical analyses were performed in $\mathrm{R}$, using the packages phyloseq (McMurdie \& Holmes 2013) for beta diversity analyses, metagenomeSeq (Paulson et al. 2013) for differential abundance testing, vegan (Oksanen et al. 2016) for ordinations and redundancy analysis, and NMF (Gaujoux 2014) for annotated heat maps. Differences in microbial composition between groups of interest were assessed, using metagenomeSeq's MR full-table function with a custom filter to determine significance: merged taxa were deemed significantly different if they exhibited a fold change (beta coefficient) of $\geq 1.25$, had an adjusted $p$-value of $\leq 0.05$ and if at least one of the two groups being compared had $\geq 20 \%$ of samples with the given OTU/taxa or the Fisher's exact test result was significant (after multiple testing correction [MTC]). OTUs were first merged at the lowest available taxonomic level (i.e. for OTUs with Lactobacillus as the lowest available taxonomic annotation counts were summed, while OTUs with additional species level annotation e.g. L. iners were summed at species level instead).

\section{Results}

A total of 149 HIV-negative 16-22-year-old women were recruited from a low-income, high-population-density community in CPT. Of the 115 women for whom 16S rRNA gene amplicon sequencing was performed (due to availability of swabs and sufficient DNA), 102 passed sequencing quality control (>5000 reads/sample). Here, we describe, for these 102 women, microbiota profiles, STI prevalence and other factors relevant to sexual and reproductive health (Table 1 ).

The median age was 18 years, and women were almost exclusively of isiXhosa ancestry (99\%). The STI prevalence was extremely high, with $55 \%$ of women diagnosed with

TABLE 1: Participant summary $(N=102)$.

\begin{tabular}{|c|c|c|}
\hline \multirow[t]{2}{*}{ Feature } & \multicolumn{2}{|c|}{ Cape Town } \\
\hline & $N$ & $\%$ \\
\hline Median age & 18 & - \\
\hline \multicolumn{3}{|l|}{ BV prevalence } \\
\hline BV-positive & 56 & 55 \\
\hline BV-intermediate & 7 & 7 \\
\hline BV-negative & 39 & 38 \\
\hline Nugent score (mean) & 5.5 & - \\
\hline STI (any) $\dagger$ & 56 & 55 \\
\hline Chlamydia trachomatis & 45 & 44 \\
\hline Neisseria gonorrhoeae & 14 & 14 \\
\hline Trichomonas vaginalis & 6 & 6 \\
\hline Mycoplasma genitalium & 4 & 4 \\
\hline HSV-2 & 6 & 6 \\
\hline \multicolumn{3}{|l|}{ HPV risk } \\
\hline High & 42 & 41 \\
\hline Low & 29 & 28 \\
\hline Negative & 31 & 31 \\
\hline \multicolumn{3}{|l|}{ Hormonal contraceptives } \\
\hline DMPA & 19 & 19 \\
\hline Implanon & 8 & 8 \\
\hline Net-En & 70 & 68 \\
\hline$O C P$ & 4 & 4 \\
\hline Nuvaring & 1 & 1 \\
\hline \multicolumn{3}{|l|}{ Ethnicity: } \\
\hline Xhosa & 94 & 99 \\
\hline Zulu & 1 & 1 \\
\hline BMI (mean) & 25.4 & - \\
\hline
\end{tabular}

$\dagger$. Other STIs tested (HSV-1, H. ducreyi, T. pallidum and L. venereum), were not detected in any of the women; HPV was not included in the classification of STI (any); $\$$, Ethnicity information was not available for seven women.

STI, sexually transmitted infection; HPV, human papilloma virus; BMI, body mass index. 
at least one STI by PCR. The majority of infections were C. trachomatis $(44 \%)$, followed by $N$. gonorrhoeae $(14 \%)$, T. vaginalis (6\%), HSV-2 (6\%) and M. genitalium (4\%); other STIs tested (HSV-1, H. ducreyi, T. pallidum and L. venereum), were not detected in any of these women. STI co-infections were frequent with $17 \%$ of women co-infected with two or more STIs (Table 2). Similarly, BV rates were very high, with $55 \%$ of women classified as BV-positive (Nugent score $\geq 7$ ), $7 \%$ as BV-intermediate (Nugent score $3-6$ ) and $38 \%$ as BV-negative (Nugent 0-2). BV-positive women were more likely to have Chlamydia (52\% vs $38 \%$ of BV-positive and BV-negative women had Chlamydia), but this relationship was not significant, neither was there a significant association with having any one or more STIs and BV. All 102 women were on HCs, with the majority using the progestin-only injectables Net-En (68\%) or DMPA (19\%).

\section{Vaginal microbiota profiling}

Unsupervised clustering of microbiota profiles demonstrate a strong concordance between increased microbial diversity by $16 \mathrm{~S}$ rRNA gene amplicon sequencing and BV status (Figure 1). Among BV-negative women L. iners or L. crispatus were by far the most abundant taxa, with significantly less diverse vaginal microbiota, compared with BV-positive (1.6e$7)$ or BV-intermediate $(p=0.03)$ women. Among BV-positive and -intermediate women, BVAB1 was the most relative abundant species in $32 \%$ of women, followed by G. vaginalis (17\%), Prevotella (16\%), Megasphaera, L. iners (10\%) and L. crispatus (5\%), Figure 2.

Using our custom taxonomic annotation pipeline, we were able to resolve all Lactobacilli down to species level. The species present were: L. iners, L. reuteri, L. crispatus, L. ruminis, L. coleohominis, L. jensenii, and L. delbrueckii. Prevotella was also represented by several species: 12 of 19 Prevotella OTUs could be resolved at species level of which $P$. amnii, P. bivia, $P$. timonensis, $P$. disiens and P. pallens together accounted for $\geq 50 \%$ of Prevotella counts in $68 \%$ of BV-positive and BVintermediate women (Figure 2), while Prevotella of unknown species made up $\geq 50 \%$ in another $27 \%$ of BV-positive/ intermediate women.

TABLE 2: Frequency distribution of sexually transmitted infections $(N=102)$ where $1=$ positive and $0=$ negative, e.g. $8 \%$ of women were diagnosed with both Chlamydia trachomatis and Neisseria gonorrhoeae.

\begin{tabular}{lccccc}
\hline $\begin{array}{c}\text { Chlamydia } \\
\text { trachomatis }\end{array}$ & $\begin{array}{c}\text { Neisseria } \\
\text { gonorrhoeae }\end{array}$ & $\begin{array}{c}\text { Trichomonas } \\
\text { vaginalis }\end{array}$ & $\begin{array}{c}\text { Mycoplasma } \\
\text { genitalium }\end{array}$ & HSV-2 & $\begin{array}{c}\text { Frequency } \\
\text { (N) }\end{array}$ \\
\hline 0 & 0 & 0 & 0 & 0 & 46 \\
0 & 0 & 0 & 0 & 1 & 2 \\
0 & 0 & 0 & 1 & 0 & 1 \\
0 & 0 & 1 & 0 & 0 & 4 \\
0 & 1 & 0 & 0 & 0 & 3 \\
0 & 1 & 1 & 0 & 0 & 1 \\
1 & 0 & 0 & 0 & 0 & 29 \\
1 & 0 & 0 & 0 & 1 & 3 \\
1 & 0 & 0 & 1 & 0 & 2 \\
1 & 0 & 1 & 0 & 0 & 1 \\
1 & 1 & 0 & 0 & 0 & 8 \\
1 & 1 & 0 & 0 & 1 & 1 \\
1 & 1 & 0 & 1 & 0 & 1 \\
\hline
\end{tabular}

Differential abundance testing between BV-positive versus BV-negative women, produced 41 significant taxa (Figure 3). As expected, BVAB1, BVAB2, BVAB3, G. vaginalis, Megasphaera, and several Prevotella species were more abundant in BV-positive women. Lactobacilli, including L. crispatus, L. reuteri, L. jensenii, L. iners and L. delbrueckii, were significantly more abundant in BV-negative women.

Group B Streptococcus carriage rates were determined from 16S rRNA gene amplicon sequencing: $25 \%$ of BV-positive women and $28 \%$ of BV-negative women were colonised by $S$. agalactiae, which was significantly more abundant among BV-negative women $(\mathrm{FC}=1.4, \mathrm{Adj} . p=0.02)$ (see Figure 4).

\section{Discussion}

Here we describe STI and BV prevalence rates and vaginal microbiota profiles among 16-22-year-old women from a resource-poor area in CPT. These women have extremely high STI rates (55\%). High-risk HPV was found in $41 \%$ of women, with a further $28 \%$ with low-risk HPV. A staggering $44 \%$ of women were infected with Chlamydia, $16 \%$ of whom had at least one additional STI. The Chlamydia infection rate among these women is substantially higher than reported among young sexually active women from other parts of SA, including rural KwaZulu-Natal (25\%) (Kleppa et al. 2015) and a different area in Cape Town (15\%) (Menezes et al. 2017). STI management remains problematic in developing countries where laboratory-based testing is frequently unavailable and where quality of STI care may be lacking (availability of medications, adherence to STI guidelines, condom provision and partner notification counselling [Kohler et al. 2017]). According to the SA Department of Health guidelines (Department of Health 2015) women qualify for STI treatment, based on a combination of demographic characteristics, symptoms or clinical observations, where STI treatment entails a combination of metronidazole, azithromycin and ceftriaxone (Peters et al. 2014). Chlamydia is typically asymptomatic, leaving most women with Chlamydia infections in SA untreated. Persistent Chlamydia infections may, however, lead to infertility, PID, increased risk of ectopic pregnancy, and miscarriage (Anschuetz et al. 2012; Baud et al. 2011; Gottlieb et al. 2013; Haggerty et al. 2010). Chlamydia is also associated with an increased risk of HIV acquisition (Buckner et al. 2016), further underscoring the need for more rigorous STI screening in this community.

Bacterial vaginosis-positive women were more likely to have Chlamydia, but this relationship was not significant, neither was there a significant association with having any one or more STIs and BV. Previous reports indicate a positive association between concurrent Chlamydia or Gonorrhea and BV (Wiesenfeld et al. 2003), although this association is not always apparent cross-sectionally, but rather longitudinally where incident BV is associated with an increased risk of having incident Gonorrhea or Chlamydia at a follow-up visit and vice versa (Gallo et al. 2012). 


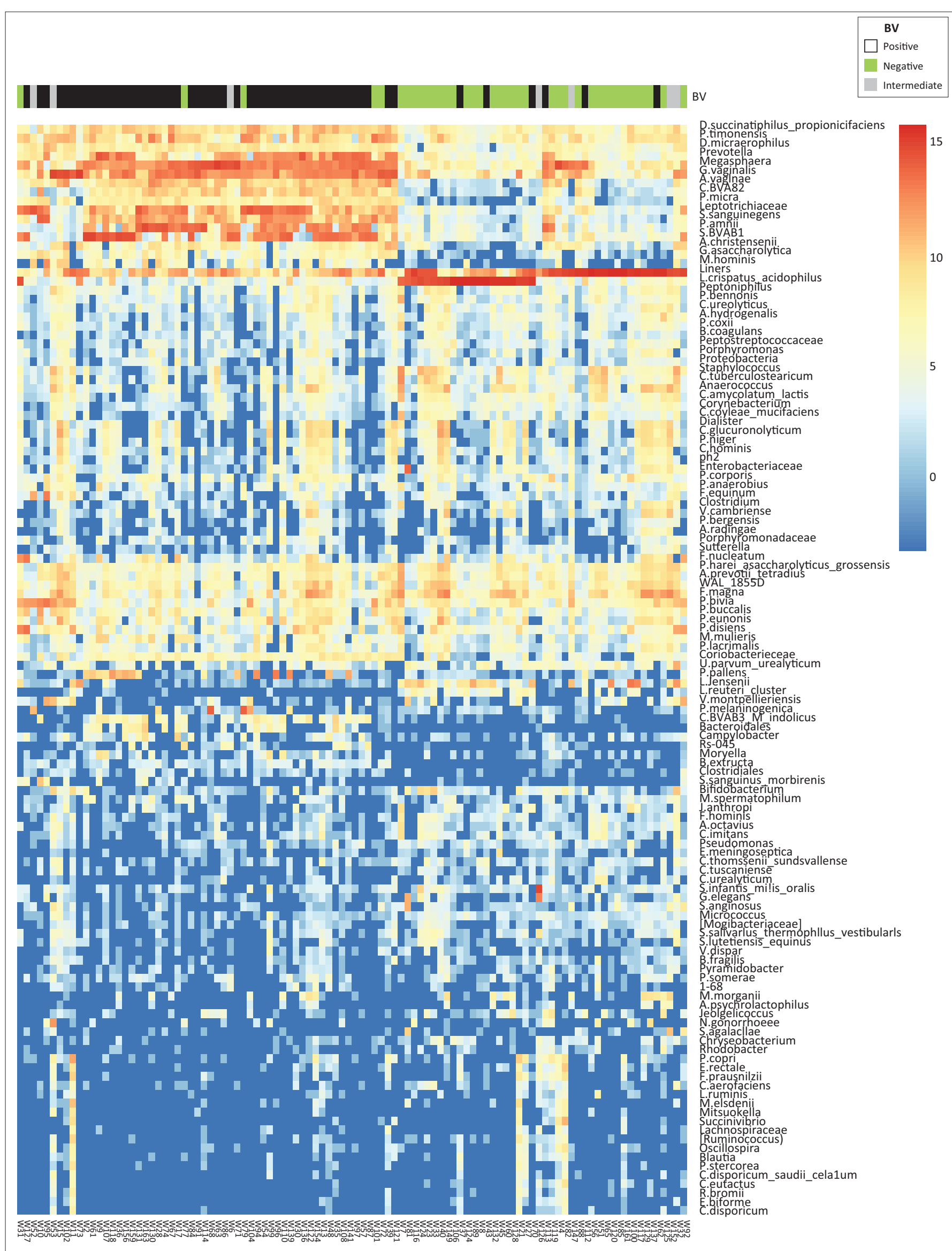

FIGURE 1: Heat map of most abundant taxa (rows) identified by $16 S$ rRNA gene microbiome profiling, using unsupervised hierarchical clustering with Bray-Curtis distance in all samples (columns). Operational taxonomic units (OTUs) were merged at the lowest available taxonomic annotation after excluding rare and low abundance OTUs (with a requirement of at least 20 counts in at least $30 \%$ of samples for a given OTU). 


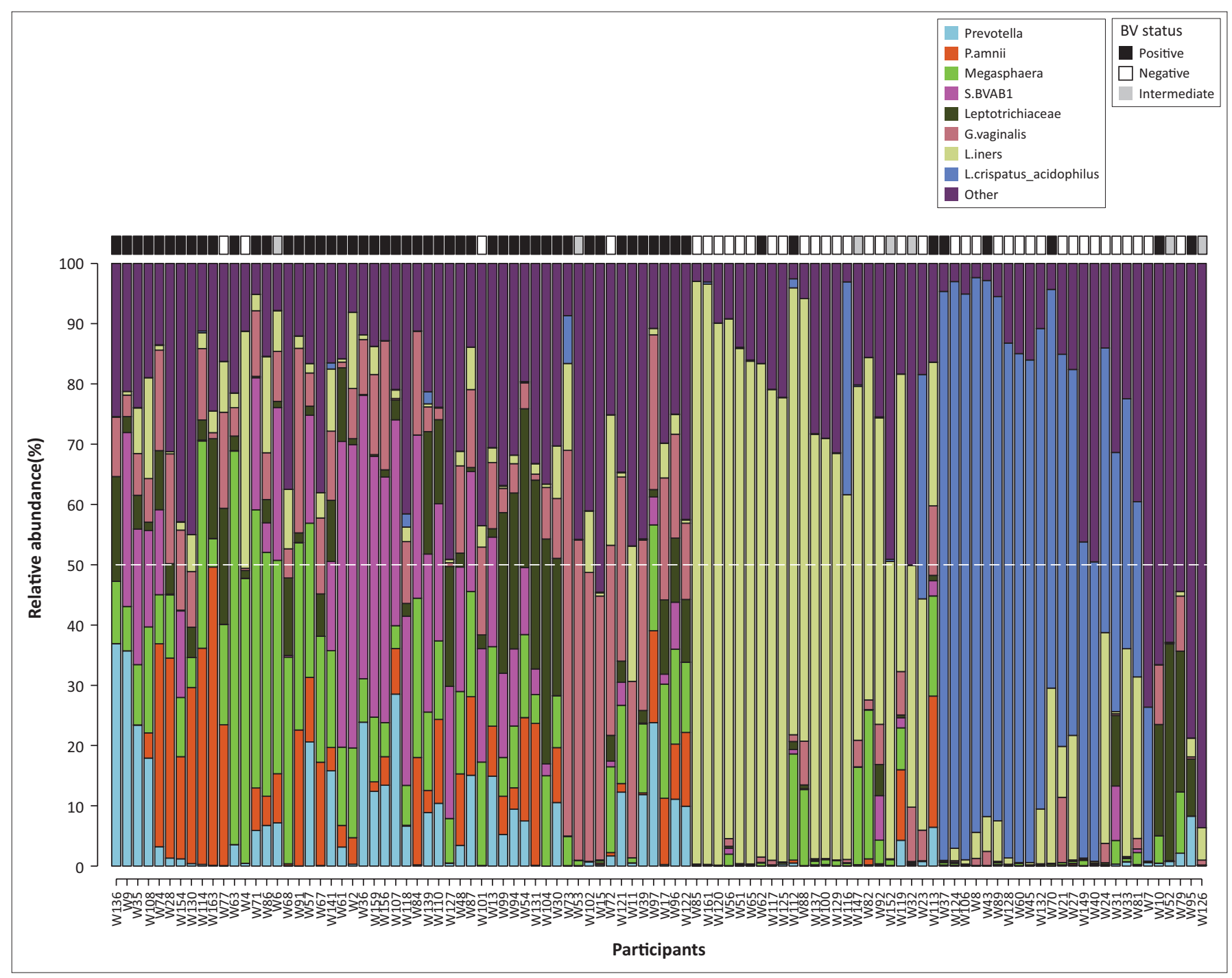

FIGURE 2: Barplot summary of individual microbiota profiles, grouped by the dominant taxa with composite bars, ordered by decreasing proportion of the dominant taxon. Black, white and grey boxes at the top indicate bacterial vaginosis (BV+), BV-and BV-intermediate status, respectively.

Bacterial vaginosis rates in SA are generally extremely high $(34 \%-58 \%)$, relative to other countries (Kenyon et al. 2013), which is confirmed in this study where $55 \%$ of women were BV-positive. As in other settings, women with Nugent scores $>7$ had highly diverse vaginal microbiota. Similar to previous studies in women of African descent, these BVpositive women frequently had vaginal microbiota, dominated by BVAB1, Prevotella, G. vaginalis or L. iners (Fettweis et al. 2014).

We were able to resolve several Prevotella OTUs down to species level. Both P. amnii and P. bivia have been associated with genital inflammation (Anahtar et al. 2015; Gosmann et al. 2017; Lennard et al. 2017) and BV, yet in this study P. bivia levels did not differ by BV status or inflammation (Lennard et al. 2017). Fettweis et al. (2014) previously reported that $P$. amnii is more prevalent in African American women, compared to women of European ancestry, which may explain the high rates of $P$. amnii colonisation seen here. In East African commercial sex workers, however, $P$. timonensis is reportedly more prevalent than P. amnii (Schellenberg et al. 2011). Therefore colonisation by P. amnii appears to be particularly common in this study population where all women were colonised by varying levels of $P$. amnii (irrespective of BV status), compared with only $10 \%$ and $50 \%$ of BV-negative and BV-positive women in Srinivasan et al. ([2012], in a study population where $34 \%$ of participants were black people). Whether these differences can be ascribed to race, geographical location or technical aspects are not clear.

Group B Streptococcus colonisation rates vary widely, occurring in $\sim 12 \%-22 \%$ of women in developed and developing countries (Stoll \& Anne 1998), with rates of $0 \%$ and $23 \%$ reported among adolescent and adult South African women, respectively (Cools et al. 2016). We found no difference in the frequency of GBS colonisation by BV status; however, BV-negative women colonised by GBS did have significantly higher levels of GBS compared with BV-positive women. GBS abundance has previously been shown to be positively associated with increased risk of adverse birth outcomes. Cools et al. (2016) found BV-negative women to be more frequently colonised by GBS; Ekström et al. (2013) reported a non-significant increase in GBS colonisation frequency in BV-negative (23.5\%), compared with BV-positive 


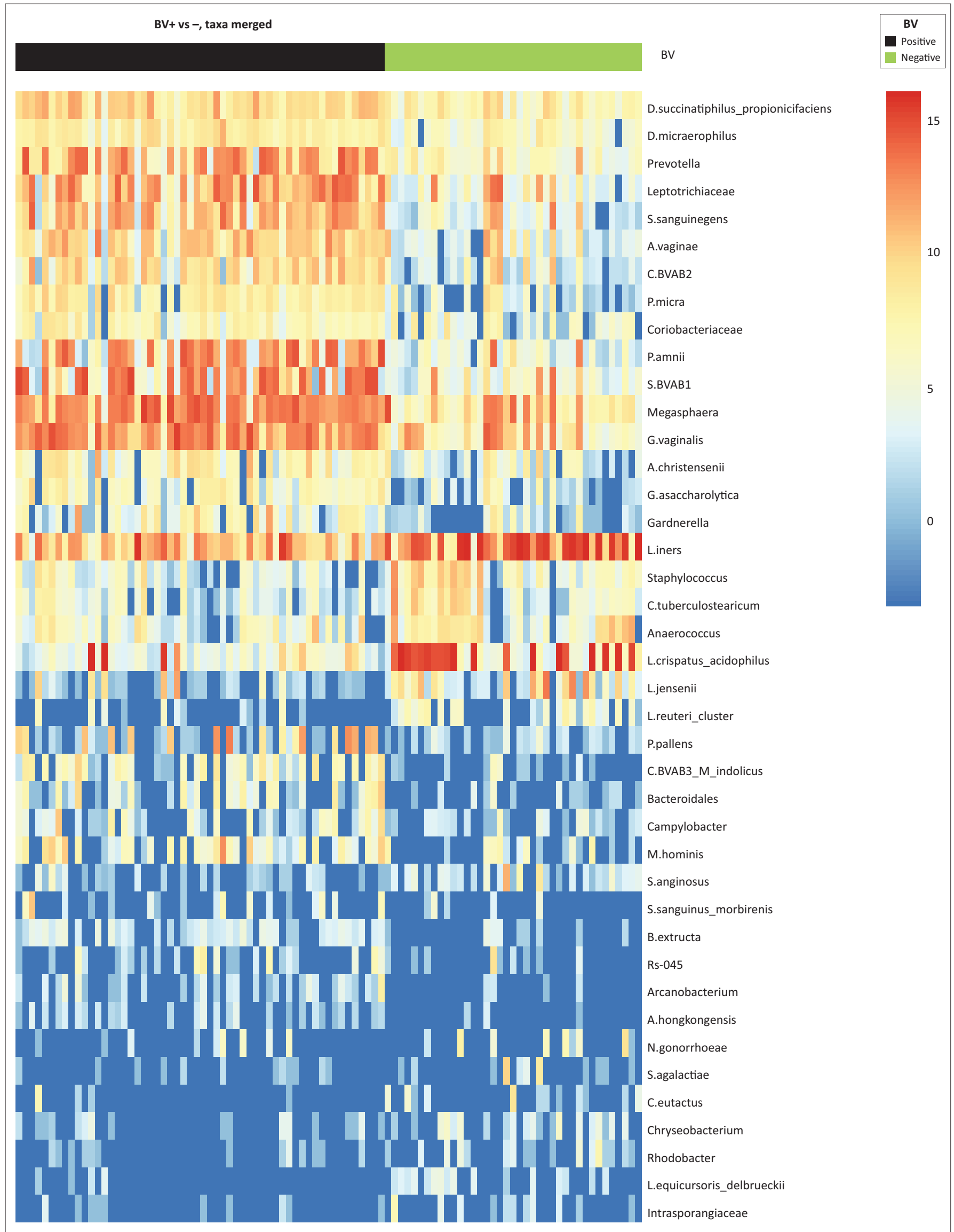

FIGURE 3: Heatmap of taxa significantly differentially abundant or frequent in BV-positive versus BV-negative women (FDR $\leq 0.05$, coefficient $\geq 1.25$, taxa present in $\geq 20 \%$ of samples in at least one of the two groups being compared); samples (columns) were sorted by BV classification; heat map scale: log2-transformed standardised counts. 


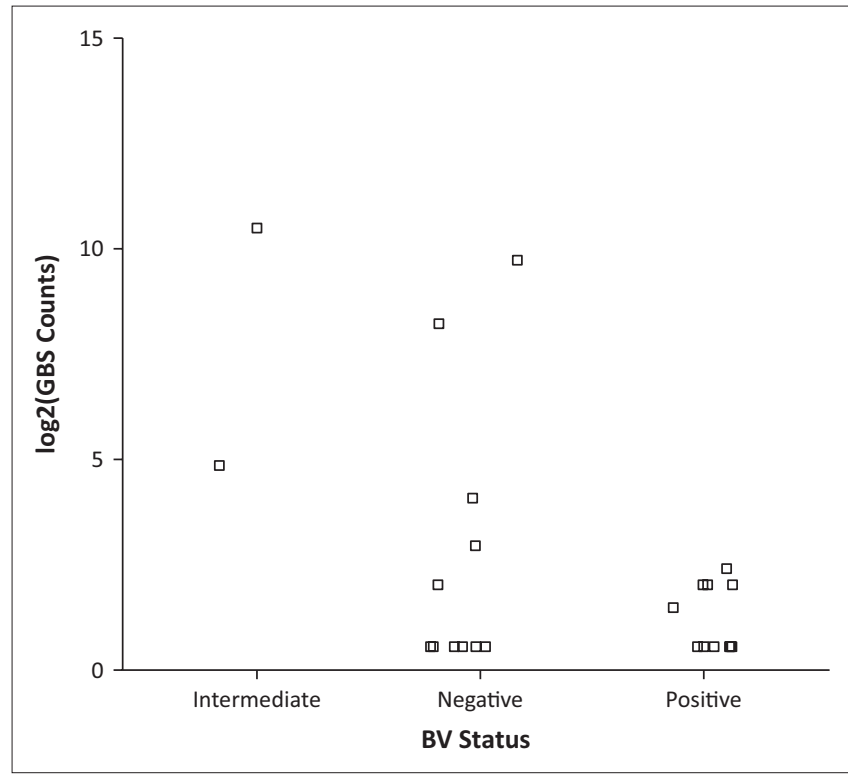

FIGURE 4: Group B. Streptococcus carriage rates stratified by bacterial vaginosis status.

women (17\%); while Srinivasan et al. (2012) found no difference. In our study the non-Group B Streptococcus S. anginosus was also significantly more abundant in BVnegative women.

In conclusion, young 16-22-year old women in this resourcepoor CPT community have a high incidence of STIs, particularly Chlamydia and high-risk HPV, as well as BV. Both Chlamydia infection and BV may adversely affect reproductive health and place these women at additional risk for HIV acquisition. The high abundance of P. amnii in particular may increase HIV risk, given its inflammatory capacity. Laboratory-based testing for STIs (Chlamydia and Gonorrhoeae in particular) appear to be warranted in this community together with further monitoring or treatment of BV.

\section{Ethical consideration}

Approval was obtained for the study from the Research Ethics Committees of the University of Cape Town.

\section{Acknowledgements}

We thank the WISH Study Teams, particularly Ms Pinky Ngobo, Sr Nozipho Hadebe, Sr Janine Nixon, and all the young women who kindly participated in the study. We thank Prof. Lynn Morris, David Lewis, Venessa Maseko and Raveshni Durgiah from the National Institute for Communicable Diseases for their help with sample processing. Computations were performed using facilities provided by the University of Cape Town's ICTS High Performance Computing team: http:/ /hpc.uct.ac.za.

This study was supported by grants from the European and Developing Countries Clinical Trials Partnership (EDCTP), Strategic Primer grant [SP.2011.41304.038] and the South African Department of Science and Technology [DST/CON
0260/2012]. K.S.L. is supported by the National Research Foundation and the Suid-Afrikaanse Akademie vir Wetenskap en Kuns. H.B.J. was supported in part by K08HD069201. SLB was supported by the HIV Vaccine Trials Network SHAPe Program, the Fogarty Foundation and the South African Medical Research Council (MRC). S.D. was supported by the National Research Foundation of South Africa. The DTHF also recognises the support from ViiV healthcare in their YouthShield program. The Perinatal HIV Research Unit (PHRU) was supported through funding from the South African Medical Research Council.

\section{Competing interests}

The authors declare that they have no financial or personal relationships that may have inappropriately influenced them in writing this article.

\section{Authors' contributions}

H.B.J., J.A.P., K.L. Recruited the cohort: G.G., S.L.B., L.G.B. conceived and designed the experiments. S.D., S.B., E.H., S.Z.J. Analyzed the data: K.L., S.D., J.A.P., G.B. performed wet lab experiments and K.L., J.A.P., H.B.J., S.L.B., S.D., L.G.B., E.H., N.M., N.N.M., S.Z.J., G.G., G.B. wrote the manuscript.

\section{References}

Anahtar, M.N., Byrne, E.H., Doherty, K.E., Bowman, B.A., Yamamoto, H.S., Soumillon, M. et al., 2015, 'Cervicovaginal bacteria are a major modulator of host inflammatory responses in the female genital tract', Immunity 42, 965-976. https://doi.org/10.1016/j.immuni.2015.04.019

Anschuetz, G.L., Asbel, L., Spain, C.V., Salmon, M., Lewis, F., Newbern, E.C. et al., 2012 'Association between enhanced screening for Chlamydia trachomatis and Neisseria gonorrhoeae and reductions in sequelae among women', Journal of Adolescent Health 51, 80-85. https://doi.org/10.1016/j.jadohealth.2011.11.002

Atashili, J., Poole, C., Ndumbe, P.M., Adimora, A.A. \& Smith, J.S., 2008, 'Bacterial vaginosis and HIV acquisition: A meta-analysis of published studies', AIDS 22(12) 1493-1501. https://doi.org/10.1097/QAD.0b013e3283021a37

Balkus, J.E., Richardson, B.A., Rabe, L.K., Taha, T.E., Mgodi, N., Kasaro, M.P. et al., 2014, 'Bacterial vaginosis and the risk of trichomonas vaginalis acquisition among HIV-1-negative women', Sexually Transmitted Diseases 41, 123-8. https://doi. org/10.1097/OLQ.0000000000000075

Baud, D., Goy, G., Jaton, K., Osterheld, M.C., Blumer, S., Borel, N. et al., 2011, 'Role of Chlamydia trachomatis in miscarriage', Emerging Infectious Diseases 17, 16301635. https://doi.org/10.3201/eid1709.100865

Buckner, L.R., Amedee, A.M., Albritton, H.L., Kozlowski, P.A., Lacour, N., McGowin, C.L. et al., 2016, 'Chlamydia trachomatis infection of endocervical epithelial cells enhances early HIV transmission events', PLoS One 11, 1-20. https://doi. org/10.1371/journal.pone.0146663

Buvé, A., Jespers, V., Crucitti, T. \& Fichorova, R.N., 2014, 'The vaginal microbiota and susceptibility to HIV', Aids 28, 2333-2344. Nature Methods 7(5), 335-336. https:// doi.org/10.1038/nmeth.f.303 https://doi.org/10.1097/QAD.0000000000000432

Caporaso, J.G., Kuczynski, J., Stombaugh, J., Bittinger, K., Bushman, F.D., Costello, E.K. et al., 2010, 'QIIME allows analysis of high-throughput community sequencing data', Nature Methods 7, 335-336.

Cools, P., Jespers, V., Hardy, L., Crucitti, T., Delany-Moretlwe, S., Mwaura, M. et al., 2016, 'A multi-country cross-sectional study of vaginal carriage of group B streptococci (GBS) and Escherichia coli in resource-poor settings: Prevalences and risk factors', PLoS One 11, 1-30. https://doi.org/10.1371/journal.pone.0148052

Department of Health, 2015, Sexually transmitted infections management guidelines 2015, Department of Health, Republic of South Africa, pp. 4-26.

Edgar, R.C., 2010, 'Search and clustering orders of magnitude faster than BLAST', Bioinformatics 26, 2460-2461, https://doi.org/10.1093/bioinformatics/btq461

Edgar, R.C., Haas, B.J., Clemente, J.C., Quince, C. \& Knight, R., 2011, 'UCHIME improves sensitivity and speed of chimera detection', Bioinformatics 27, 2194-2200. https://doi.org/10.1093/bioinformatics/btr381

Edmond, K.M., Kortsalioudaki, C., Scott, S., Schrag, S.J., Zaidi, A.K., Cousens, S. \& Heath, P.T., 2012, 'Group B streptococcal disease in infants aged younger than 3 months: Systematic review and meta-analysis', Lancet 379, 547-556, https://doi. org/10.1016/S0140-6736(11)61651-6 
Ekström, L., Adolfsson, A., Ericson, H., Poutakidis, G., Charonis, G. \& Larsson, P-G., 2013, 'Vaginal flora and urinary and vaginal group B streptococci in early pregnancy', Gynecology 1, 5. https://doi.org/10.7243/2052-6210-1-6

Ferlay, J., Soerjomataram, I., Dikshit, R., Eser, S., Mathers, C., Rebelo, M. et al., 2015, 'Cancer incidence and mortality worldwide: Sources, methods and major patterns in GLOBOCAN 2012', International Journal of Cancer 136, E359-E386.

Fettweis, J.M., Paul Brooks, J., Serrano, M.G., Sheth, N.U., Girerd, P.H., Edwards, D.J. et al., 2014, 'Differences in vaginal microbiome in African American women versus women of European ancestry', Microbiology 160, 2272-2282.

Fettweis, J.M., Serrano, M.G., Sheth, N.U., Mayer, C.M., Glascock, A.L. et al., 2012, 'Species-level classification of the vaginal microbiome', BMC Genomics 13, S17.

Gallo, M.F., Macaluso, M., Warner, L., Fleenor, M.E., Hook, E.W., Brill, I. \& Weaver, M.A., 2012, 'Bacterial Vaginosis, Gonorrhea, and Chlamydial infection among women attending a sexually transmitted disease clinic: A longitudinal analysis of possible causal links', Annals of Epidemiology 22, 213-220. https://doi.org/10.1016/j. annepidem.2011.11.005

Gaujoux, R., 2014, Generating heatmaps for Nonnegative Matrix Factorization, viewed n.d., from http://nmf.r-forge.r-project.org/vignettes/heatmaps.pdf

Gosmann, C., Anahtar, M.N., Handley, S.A., Walker, B.D., Virgin, H.W., Kwon, D.S. et al., 2017, 'Lactobacillus-deficient cervicovaginal bacterial communities are associated

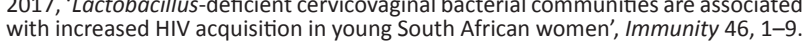
with increased HIV acquisition in young South
https://doi.org/10.1016/j.immuni.2016.12.013

Gottlieb, S.L., Xu, F. \& Brunham, R.C., 2013, Screening and treating chlamydia trachomatis genital infection to prevent pelvic inflammatory disease, Sexually Transmitted Diseases 40, 1. https://doi.org/10.1097/OLQ.0b013 Sexually Transm

Haggerty, C.L., Gottlieb, S.L., Taylor, B.D., Low, N., Xu, F. \& Ness, R.B., 2010, 'Risk of sequelae after Chlamydia trachomatis genital infection in women', The Journal of Infectious Diseases 201, 134-155. . https://doi.org/10.1086/652395

Harries, J., Moodley, J., Barone, M.A., Mall, S. \& Sinanovic, E., 2009, 'Preparing for HPV vaccination in South Africa: Key challenges and opinions', Vaccine $27,38-44$. https://doi.org/10.1016/j.vaccine.2008.10.033

Jacobs, M. V, Snijders, P.J., Helmerhorst, T.J., Meijer, J. \& Walboomers, J.M., 1997, 'A general primer GP5+ / GP6 + -mediated PCR-enzyme immunoassay method for rapid detection of 14 high-risk and 6 low-risk human papillomavirus genotyps in cervical scrapings', Journal of Clinical Microbiology 35, 791.

Kenyon, C., Colebunders, R. \& Crucitti, T., 2013, 'The global epidemiology of bacteria vaginosis: A systematic review', American Journal of Obstetrics and Gynecology 209, 505-523. https://doi.org/10.1016/j.ajog.2013.05.006

Kleppa, E., Holmen, S.D., Lillebø, K., Kjetland, E.F., Gundersen, S.G., Taylor, M. et al., 2015, 'Cervical ectopy: Associations with sexually transmitted infections and HIV. A cross-sectional study of high school students in rural South Africa' Sexually Transmitted Infections 91, 124-129. https://doi.org/10.1136/ sextrans-2014-051674

Kohler, P.K., Marumo, E., Jed, S.L., Mema, G., Galagan, S., Tapia, K. et al., 2017, 'A national evaluation using standardised patient actors to assess STI services in public sector clinical sentinel surveillance facilities in South Africa', Sexually Transmitted Infections sextrans-2016-052930. https://doi.org/10.1136/ sextrans-2016-052930

Lennard, K., Dabee, S., Barnabas, S.L., Havyarimana, E., Blakney, A., Jaumdally, S.Z. et al., 2012, 'Prevalence and associations of genital ulcer and urethral pathogens in men presenting with genital ulcer syndrome to primary health care clinics in South Africa', Sexually Transmitted Diseases 39, 880-5. https://doi.org/10.1128/ IAl.00410-17

Lewis, D.A., Müller, E., Steele, L., Sternberg, M., Radebe, F., Lyall, M. et al., 2012 'Prevalence and associations of genital ulcer and urethral pathogens in men presenting with genital ulcer syndrome to primary health care clinics in South Africa', Sexually Transmitted Diseases 39, 880-5. https://doi.org/10.1097/ OLQ.0b013e318269cf90
Madhi, S.A., Radebe, K., Crewe-Brown, H., Frasch, C.E., Arakere, G., Mokhachane, M. \& Kimura, A., 2003, 'High burden of invasive Streptococcus agalactiae disease in South African infants', Annals of Tropical Paediatrics 23, 15-23. https://doi. in South African infants', Annals of
org/10.1179/000349803125002814

Masson, L., Passmore, J.S., Liebenberg, L.J., Werner, L., Baxter, C., Arnold, K.B. et al., 2015, 'Genital inflammation and the risk of HIV acquisition in women', Clinical Infectious Diseases 61(2), 1-10. https://doi.org/10.1093/cid/civ298

Mchunu, G., Peltzer, K., Tutshana, B. \& Seutlwadi, L., 2012, 'Adolescent pregnancy and associated factors in South African youth', African Health Sciences 12, 426-434. https://doi.org/10.4314/ahs.v12i4.5

McMurdie, P.J. \& Holmes, S., 2013, 'Phyloseq: An R package for reproducible interactive analysis and graphics of microbiome census data', PLoS One 8, e61217. https://doi.org/10.1371/journal.pone.0061217

Menezes, L.J., Pokharel, U., Sudenga, S.L., Botha, M.H., Zeier, M., Abrahamsen, M.E. et al., 2017, 'Patterns of prevalent HPV and STI co-infections and associated factors among HIV-negative young Western Cape, South African women: The EVR trial', Sexually Transmitted Infections sextrans-2016-053046. https://doi. org/10.1136/sextrans-2016-053046

Mkhize, N.N., Bekker, L.-G., Lewis, D.A., Gray, G., Mulder, N., Passmore, J.-A.S. \& Jaspan, H.B., 2017, 'Microbial composition predicts genital tract inflammation and persistent bacterial vaginosis in adolescent South African women', Infection and Immunity IAI.00410-17. https://doi.org/10.1128/IAI.00410-17

Myer, L., Denny, L., Telerant, R., De Souza, M., Wright, T.C. \& Kuhn, L., 2005, 'Bacterial vaginosis and susceptibility to HIV infection in South African women: A nested case-control study, Journal of Infectious Diseases 192(8), 1372-1380. https://doi.org/10.1086/462427

Oksanen, A.J., Blanchet, F.G., Kindt, R., Legendre, P., Minchin, P.R., Hara, R.B.O. et al. 2016, 'Vegan: Community ecology package. R package vegan, vers. 2.2-1', World Agroforestry Centre United Nations Avenue, Gigiri.

Paulson, J.N., Stine, O.C., Bravo, H.C. \& Pop, M., 2013, 'Differential abundance analysis for microbial marker-gene surveys', Nature Methods 10, 1200-1202. https://doi. for microbial marker-gene

Pearce, M.M., Hilt, E.E. \& Rosenfeld, A.B., 2014, 'The female urinary microbiome: A comparison of women with and without urgency urinary incontinence', mBio 5(4), 1-12. https://doi.org/10.1128/mBio.01283-14

Peters, R.P.H., Dubbink, J.H., Van der Eem, L., Verweij, S.P., Bos, M.L.A., Ouburg, S. et al., 2014, 'Cross-sectional study of genital, rectal, and pharyngeal Chlamydia and Gonorrhea in women in rural South Africa', Sexually Transmitted. Diseases 41 564-569.

Ravel, J., Gajer, P., Abdo, Z., Schneider, G.M., Koenig, S.S.K., Mcculle, S.L. et al., 2010, 'Vaginal microbiome of reproductive-age women', Proceedings of the Nationa Academy of Sciences of the United States of America (PNAS) 108, 4680-4687.

Schellenberg, J.J., Links, M.G., Hill, J.E., Dumonceaux, T.J., Kimani, J., Jaoko, W. et al., 2011, 'Molecular definition of vaginal microbiota in East African commercial sex workers', Applied and Environmental Microbiology 77, 4066-4074. https://doi. org/10.1128/AEM.02943-10

Srinivasan, S., Hoffman, N.G., Morgan, M.T., Matsen, F.A., Fiedler, T.L., Hall, R.W. et al., 2012, 'Bacterial communities in women with Bacterial Vaginosis: High resolution phylogenetic analyses reveal relationships of microbiota to clinical criteria', PLOS One 7(6), e37818. https://doi.org/10.1371/journal.pone.0037818

Stoll, B.J. \& Anne, S., 1998, 'Maternal carriage of group B streptococci in developing countries', Pediatric Infectious Disease Journal 17(6), 499-503. https://doi. org/10.1097/00006454-199806000-00013

Taha, T.E., Hoover, D.R., Dallabetta, G. a, Kumwenda, N.I., Mtimavalye, L.A, Yang, L.P. et al., 1998, 'Bacterial vaginosis and disturbances of vaginal flora: Association with increased acquisition of HIV', AIDS 12, 1699-1706. https://doi. org/10.1097/00002030-199813000-00019

Wiesenfeld, H.C., Hillier, S.L., Krohn, M.A., Landers, D.V. \& Sweet, R.L., 2003, 'Bacterial vaginosis is a strong predictor of Neisseria gonorrhoeae and Chlamydia trachomatis infection', Clinical Infectious Diseases 36, 663-668. https://doi.org/10.1086/367658 